\title{
INTERACTION OF COMPETITIVE
}

\section{ANTAGONISTS: THE ANTI-CURARE ACTION OF HEXAMETHONIUM AND OTHER ANTAGONISTS AT THE SKELETAL NEUROMUSCULAR JUNCTION}

\author{
J.G. BLACKMAN, R.W. GAULDIE \& R.J. MILNE \\ Department of Pharmacology, University of Otago Medical School, Dunedin, New Zealand
}

1 In the rat isolated diaphragm preparation hexamethonium and other low potency competitive antagonists of acetylcholine ( $\mathrm{ACh}$ ), including gallamine and hyoscine butylbromide, reverse block by the potent antagonists tubocurarine, pancuronium and alcuronium.

2 In the presence of tubocurarine, hexamethonium increases the amplitude of the end-plate potential without increasing the quantal content. It enhances the response to ACh applied iontophoretically to the end-plate but does not enhance the response to ACh applied in the bath.

3 The anti-curare effect of hexamethonium is abolished in the diaphragm of the rat, guinea-pig and mouse by inhibitors of acetylcholinesterase. The effect is not observed in the indirectly stimulated toad sartorius muscle.

4 The effect is explained if tubocurarine does not dissociate appreciably in the time taken for ACh to achieve high occupancy of receptors, so that a fraction of receptors is completely excluded from occupation by ACh. Equilibration with hexamethonium reduces the fraction excluded by tubocurarine and the transmitter now competes with hexamethonium for more receptors and produces a larger response.

5 On the basis of this explanation the half-time for dissociation of tubocurarine must be about 1 millisecond. It follows that tubocurarine does not act competitively with ACh at synapses when transmitter action is sufficiently brief, and that its binding to the receptor is probably diffusion-limited.

\section{Introduction}

It appears self-evident that block caused by one competitive antagonist should be enhanced by another. However, it has been demonstrated (Stephenson \& Ginsborg, 1969) on the basis of the mass-law description of drug-receptor interaction that this need not apply when one antagonist does not dissociate appreciably from the receptors during application of the agonist, and the other is able to compete with the agonist for the unoccupied receptors. Stephenson \& Ginsborg (1969) suggested that these conditions might be found during block of transmission at the skeletal neuromuscular junction. Ferry \& Marshall (1971) have described an anti-curare action of hexamethonium in the rat isolated phrenic nervediaphragm preparation and have subsequently (Ferry \& Marshall, 1973) interpreted the phenomenon in terms of the Stephenson-Ginsborg hypothesis.

In this paper we describe experiments which confirm the observations of Ferry \& Marshall, and others which indicate that the anti-curare action of hexamethonium is but one example of a more generally observable and seemingly anomalous interaction between competitive antagonists. We have found, as predicted from the mass-law theory, that low potency competitive antagonists including gallamine and hyoscine butylbromide can reverse block by high potency antagonists. The results shed light on the kinetics of the drug-receptor interaction in relation to the time course of transmitter action.

Preliminary reports of this work were given to the Physiological Society of New Zealand and to the Australian Physiological and Pharmacological Society.

\section{Methods}

\section{Rat diaphragm}

Isolated phrenic nerve-diaphragm preparations from albino rats weighing $100-200 \mathrm{~g}$ were 
maintained at $32^{\circ} \mathrm{C}$ (for intracellular recordings) or at $37^{\circ} \mathrm{C}$ (for mechanical recordings) in a physiological solution of composition $(\mathrm{mmol} / \mathrm{l})$ : $\mathrm{Na}^{+} 143.5, \mathrm{~K}^{+} 5.9, \mathrm{Ca}^{2+} 2.0, \mathrm{Mg}^{2+} 1.0, \mathrm{Cl}^{-}$ $127.2, \mathrm{SO}_{4}^{2-} 1.0, \mathrm{H}_{2} \mathrm{PO}_{4}^{-} 1.2, \mathrm{HCO}_{3}^{-} 25.0$, glucose 11 , and insulin ( $1 \mathrm{iu} / 1)$; equilibrated with $95 \% \mathrm{O}_{2}$ and $5 \% \mathrm{CO}_{2}$. Intracellular recordings of membrane potentials were made with glass capillary microelectrodes filled with $\mathrm{KCl}(3 \mathrm{~mol} / \mathrm{l})$ directly coupled through a W-P Instruments M4A electrometer to an oscilloscope and chart recorder.

End-plate potentials evoked by supramaximal stimulation of the phrenic nerve at $1 \mathrm{~Hz}$ were recorded for $4 \mathrm{~min}$ from cells whose resting potentials were greater than $50 \mathrm{mV}$ and stable to within $3 \mathrm{mV}$. Solutions contained (+)-tubocurarine chloride in a concentration of $1.7 \times 10^{-6} \mathrm{~mol} / \mathrm{l}$ with or without hexamethonium in a concentration of $4 \times 10^{-4} \mathrm{~mol} /$ litre. The methosulphate of hexamethonium was used in preference to the bromide which depolarized end-plates, presumably because our samples were contaminated.

Quantal contents of end-plate potentials were calculated from the signal variance corrected for noise (Hubbard, Llinás \& Quastel, 1969): r.m.s. noise was estimated from the film record as one quarter of the peak-to-peak noise. This assumes that noise was random, and that limits fitted by eye to the baseline noise include $95 \%$ ( \pm 2 s.d.) of the total noise. Records were analysed only if the observed variance was at least $50 \%$ greater than the noise variance.

In experiments with acetylcholine (ACh) applied in the bath the depolarization was taken as the difference between the baseline value (steady within $1 \mathrm{mV}$ ) and the new steady value which was usually established within $2 \mathrm{~min}$ of the start of depolarization. Results were rejected if the depolarization due to $\mathrm{ACh}$ could not be reversed by washing.

In the iontophoretic experiment performed by Dr A.J. Harris, the micropipette containing ACh was placed close to the end-plate, and ACh was ejected using a $5 \mathrm{~ms}$ current pulse. This experiment was performed at room temperature $\left(22^{\circ} \mathrm{C}\right)$.

To test for anti-curare effects of low-potency antagonists, the twitch amplitude of indirectly stimulated muscle preparations was recorded isometrically at a resting tension of 0.05 newton (N) and stimulus frequency of $0.067 \mathrm{~Hz}$. Sufficient tubocurarine was added to the $25 \mathrm{ml}$ bath to reduce the twitch amplitude to a steady level below $50 \%$ of the control. The effect of successively adding increments equal to a tenth of the estimated $50 \%$ blocking dose of the weak antagonist was then observed. Antagonism of block by alcuronium and pancuronium was observed in the same way. Relative potencies of drugs were determined by estimating the approximate $50 \%$ blocking doses $\left(E D_{50}\right.$ 's $)$ in one diaphragm.

\section{Guinea-pig and mouse diaphragms}

Twitch amplitudes of isolated, indirectly stimulated, left hemi-diaphragms of two albino guineapigs (150-200 g) and four adult mice were recorded isometrically: resting tensions were 0.05 and $0.02 \mathrm{~N}$ tension respectively. The physiological salt solution $\left(37^{\circ} \mathrm{C}\right)$ was the same as that used for the rat diaphragm.

\section{Toad muscle}

Isolated, innervated sartorius muscles of the toad (Bufo marinus) were maintained at room temperature $\left(22^{\circ} \mathrm{C}\right)$ in a solution of composition $(\mathrm{mmol} / \mathrm{l})$ $\mathrm{Na}^{+} 112, \mathrm{~K}^{+} 2.0, \mathrm{Ca}^{2+} 1.8, \mathrm{Cl}^{-} 117.6, \mathrm{HCO}_{3}^{-} 2.4$, $\mathrm{H}_{2} \mathrm{PO}_{4}^{-}$3.0, glucose 11 . Muscle contractions were recorded isometrically at a tension of $0.1 \mathrm{~N}$ at frequencies of either $0.067 \mathrm{~Hz}$ or $1 \mathrm{~Hz}$.

\section{Materials}

Drugs used were: (+)-tubocurarine chloride (McGaw Ethicals, Auckland), alcuronium chloride (Roche), pancuronium bromide (Organon), gallamine triethiodide (M. \& B.), hexamethonium dibromide (M. \& B.), hexamethonium methosulphate, azamethonium (Ciba), hexamethylene bisethyldimethylammonium bromide (Gaplegin, M. \& B.), hyoscine butylbromide (Boehringer Ingelheim), atropine sulphate (B.D.H.), homatropine hydrochloride (MacFarlane Smith, Edinburgh), chlorisondamine (Ciba), neostigmine methylsulphate (Roche), edrophonium chloride (Roche), ecothiopate iodide (Ayerst Lab. Inc., N.Y.), physostigmine salicylate (B.D.H.).

\section{Results}

\section{A.ti-curare effect of hexamethonium}

Rat diaphragm We agree with the conclusion of Ferry \& Marshall $(1971 ; 1973)$ that the anti-curare action of hexamethonium in the rat diaphragm (see Figure 4a) is not presynaptic, and that the postsynaptic action is not due to inhibition of cholinesterase or to membrane depolarization. Thus we observed, as they did, that at a tubocurarine concentration of $1.7 \times 10^{-6} \mathrm{~mol} / 1$, hexamethonium $\left(4 \times 10^{-4} \mathrm{~mol} / \mathrm{l}\right)$ approximately doubled the amplitude of the intracellularly recorded end-plate potential without increasing the quantal content (Table 1). Hexamethonium 


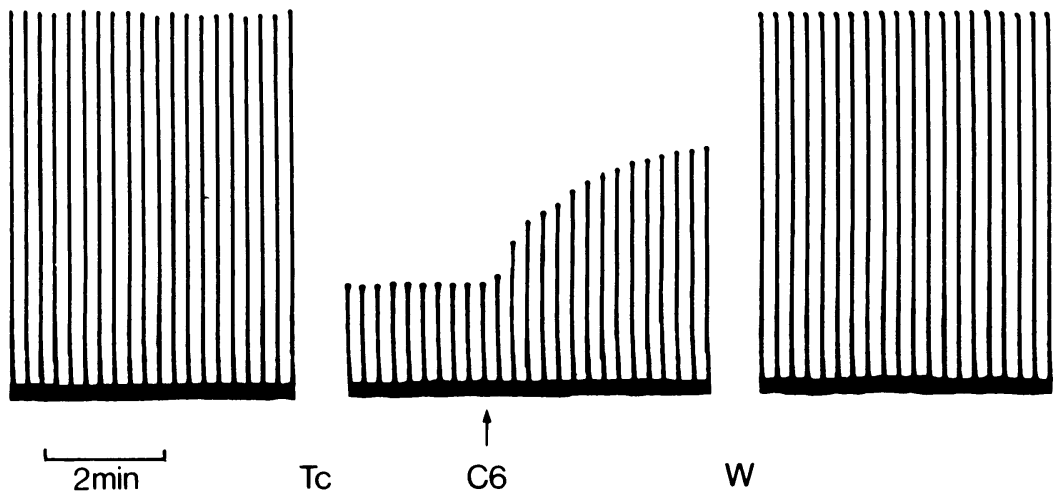

Figure 1 Anti-curare effect of hexamethonium in the indirectly stimulated guinea-pig diaphragm preparation. Tubocurarine (Tc) $\left(3 \times 10^{-6} \mathrm{~mol} / \mathrm{l}\right)$ present in centre block. Hexamethonium $(\mathrm{C} 6)\left(4 \times 10^{-4} \mathrm{~mol} / \mathrm{l}\right)$ added at arrow. Forty $\mathrm{min}$ elapsed between washout of the antagonists and the final record. Control twitch tension approximately $0.25 \mathrm{~N}$. Recording isometric.

did not increase the duration of the end-plate potential or affect the resting membrane potential recorded at the end-plate in the presence of tubocurarine. Increases in the concentration of hexamethonium beyond $4 \times 10^{-4} \mathrm{~mol} / 1$ generally caused little or no further increase in the amplitude of the end-plate potential and eventually caused greater block: acting on its own, hexamethonium causes $50 \%$ block of transmission in the rat diaphragm at a concentration of about $4 \times 10^{-3} \mathrm{~mol} / 1$ (Blackman, unpublished observations).

We have confirmed also that hexamethonium does not antagonize partial block of transmission by $\mathrm{Mg}^{2+}$. This is further evidence that hexamethonium at least in concentrations up to $10^{-3} \mathrm{~mol} / 1$ does not inhibit cholinesterase in the diaphragm, and is evidence also that hexamethonium has no effect on the passive properties of the end-plate membrane that would account for its anti-curare effect. Its action appears to depend on an interaction with tubocurarine at receptor level.
Diaphragm of other mammals The anti-curare action of hexamethonium was observed in the isolated hemi-diaphragms of two guinea-pigs (Figure 1). Similar results were observed in diaphragms from four mice. The effect in both species was characterized by a dependence on concentration, similar to that in the rat diaphragm.

Effect in the amphibian Given that the chief features of transmission at mammalian and amphibian neuromuscular junctions are fundamentally similar, we expected to observe the anticurare effect of hexamethonium at the toad sartorius neuromuscular junction. However, in this preparation, hexamethonium exhibited no anticurare effect at concentrations below $10^{-4} \mathrm{~mol} / \mathrm{l}$; at higher concentrations it simply enhanced the block by tubocurarine.

\section{Anti-curare effect of other competitive antagonists}

Table 2 demonstrates that a range of weak antagonists including hexamethonium partially

Table 1 Effect of hexamethonium on the mean amplitude and quantal content of end-plate potentials (e.p.p.) in the curarized diaphragm of the rat

\begin{tabular}{|c|c|c|c|}
\hline Treatment & No. of cells & $\begin{array}{l}\text { Mean* e.p.p. } \\
\text { amplitude }(m V)\end{array}$ & $\begin{array}{c}\text { Mean quantal } \\
\text { content }\end{array}$ \\
\hline $\begin{array}{l}\text { Tubocurarine } \\
\text { Tubocurarine plus hexamethonium }\end{array}$ & $\begin{array}{r}8 \\
12\end{array}$ & $\begin{array}{l}0.55 \pm 0.05 \\
0.93 \pm 0.11\end{array}$ & $\begin{array}{l}168 \pm 36 \\
128 \pm 14\end{array}$ \\
\hline
\end{tabular}

* Each amplitude is the mean of 180 responses measured in one cell. Concentrations (mol/I): tubocurarine, $1.7 \times 10^{-6} ;$ hexamethonium, $4.0 \times 10^{-4}$. Values given are means \pm s.e. mean. 


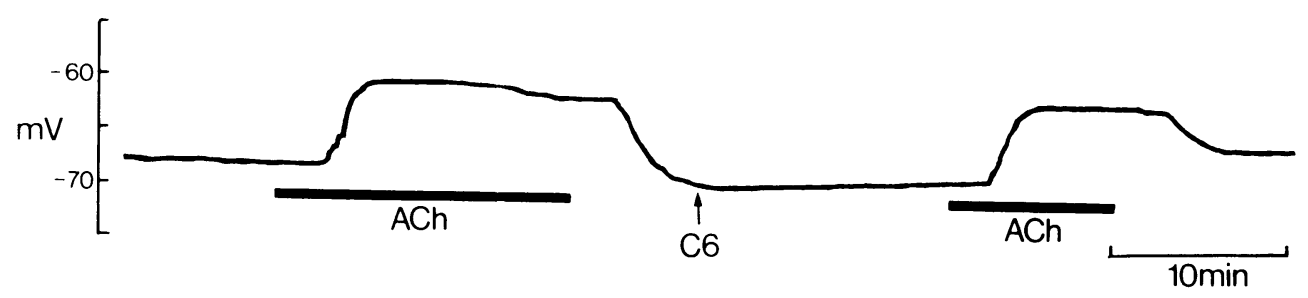

Figure 2 Failure of hexamethonium (C6: $4.0 \times 10^{-4} \mathrm{~mol} / 1$ ) to enhance the depolarization of a muscle fibre by bath-applied acetylcholine (ACh: $\left.4.0 \times 10^{-3} \mathrm{~mol} / \mathrm{l}\right)$ in the presence of tubocurarine $\left(1.7 \times 10^{-6} \mathrm{~mol} / 1\right)$. Intracellular recording.

reversed neuromuscular block produced by tubocurarine, pancuronium, and alcuronium, all of which are potent competitive antagonists. These anti-curare actions were observed at a concentration of each weak antagonist generally about $10 \%$ of its $\mathrm{ED}_{50}$ for neuromuscular block. Increasing this dose towards the $\mathrm{ED}_{50}$ ultimately enhanced block.

Hyoscine butylbromide exhibited a weak anti-curare effect against tubocurarine and alcuronium, but not against pancuronium. The antagonism of tubocurarine and alcuronium was not observed in all diaphragm preparations.

\section{Effect of other drugs}

It follows from the hypothesis that the anti-curare effect should be confined to low-potency competitive antagonists. It was of interest, therefore, to test substances known not to be competitive antagonists at the neuromuscular junction. Chlorisondamine was chosen first because it is a bis-onium compound like hexamethonium, and of similar potency, but with a non-competitive action (van Rossum \& Ariëns, 1959; Trendelenburg, 1961). It had no anti-curare effect in the rat diaphragm at any concentration (Table 2). Similarly atropine had no anti-curare effect (Table 2): its action at the neuromuscular junction has recently been shown to be non-competitive in the sense that it affects the elementary conductance change underlying the end-plate current (Katz \& Miledi, 1973b). Homatropine, also, had no anti-curare effect.

\section{Dependence on method of application of acetyl-} choline

The explanation of the anticurare action of hexamethonium favoured by Ferry \& Marshall and by ourselves is based on the mass-law description of drug-receptor interaction. It assumes that the 'slow' antagonist does not dissociate appreciably in the time taken for the agonist to achieve high occupancy of receptors. The effect should not

Table 2 Effects in the rat diaphragm of weak antagonists of acetylcholine on partial neuromuscular block by potent antagonists

\section{Tubocurarine}

Gallamine
Gaplegin"
Hexamethonium
Azamethonium
Atropine
Homatropine
Hyoscine butylbromide
Chlorisondamine

Pancuronium

+
++
++
++
-
+
+
-

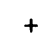

$++$

$++$

$+$

-

Approx. equipotent molar ratio

Alcuronium

+
++
++
++
-
+

86

3000

5000

6300

$2000^{2}$

Substantial reversal (see Figure 4a) is expressed as ++; a lesser degree of reversal is expressed as + and no reversal as -. Each observation was made in two or more diaphragms. Equipotent molar ratios (relative to tubocurarine) were measured in one diaphragm only. Stimulus frequency $0.067 \mathrm{~Hz}$.

a Beránek \& Vyskocil (1967).

* Hexamethylene bisethyldimethylammonium bromide. 
occur, therefore, when the agonist is applied slowly, as from the bath.

Bath application Figure 2 illustrates the result of an experiment in which the end-plate response to ACh applied in the bath was recorded from a single muscle cell before and after adding hexamethonium to the curarized diaphragm. Cells were accepted only when there was no decline in response to $\mathrm{ACh}$ over the first $5 \mathrm{~min}$ of application. In the 8 cells in which this experiment was performed, hexamethonium produced no consistent change in the depolarizing response to ACh (Table 3 ). In another set of experiments on the curarized diaphragm in which similar drug concentrations were used, the mean depolarization produced by bath-applied ACh in 13 cells was not significantly different from the depolarization produced in 13 other cells when hexamethonium was present as well (Table 4). It is evident from these 'equilibrium' experiments that hexamethonium does not potentiate the response to $\mathrm{ACh}$ in the curarized diaphragm when $\mathrm{ACh}$ is added slowly from the bath.
Iontophoretic application In an experiment kindly performed by $\operatorname{Dr}$ A.J. Harris, ACh was applied by iontophoresis to the end-plates of two cells of a curarized rat diaphragm preparation before and after adding hexamethonium. The amplitude of the ACh potential evoked by a $5 \mathrm{~ms}$ rectangular ejection pulse increased when hexamethonium was present and returned to its original level when hexamethonium was withdrawn (Figure 3 ). This result, which incidentally confirms that the mechanism of the anti-curare action of hexamethonium is postsynaptic, suggests that ACh applied from a micropipette can achieve high occupancy of receptors before appreciable dissociation of tubocurarine occurs. However, we did not determine the effect of applying ACh at different rates, or attempt to test other explanations of the anticurare effect using this technique.

\section{Influence of synaptic factors}

The result in the amphibian suggests that the occurrence of the anticurare effect of hexamethonium is critically dependent on synaptic

Table 3 End-plate depolarization of curarized rat diaphragm by bath-applied acetylcholine before and after adding hexamethonium

$\begin{array}{ccccc}\begin{array}{c}\text { Cell } \\ \text { number }\end{array} & \begin{array}{c}\text { Resting } \\ \text { membrane } \\ \text { potential }(\mathbf{m V})\end{array} & \begin{array}{c}\text { Without } \\ \text { added } \\ \text { hexamethonium }\end{array} & \begin{array}{c}\text { With } \\ \text { added } \\ \text { hexamethonium }\end{array} & \text { Difference } \\ 1 & 68 & 6.0 & 6.0 & 0.0 \\ 2 & 70 & 2.5 & 3.0 & +0.5 \\ 3 & 70 & 3.0 & 2.5 & -0.5 \\ 4 & 60 & 2.3 & 3.5 & +1.2 \\ 5 & 65 & 5.0 & 5.5 & +0.5 \\ 6 & 64 & 1.2 & 3.0 & +1.8 \\ 7 & 56 & 3.0 & 2.5 & -0.5 \\ 8 & 60 & 2.3 & 2.0 & -0.3 \\ \text { Mean } & & 3.16 & 3.50 & +0.30 *\end{array}$

Drug concentrations (mol/l): acetylcholine $4 \times 10^{-3}$; tubocurarine $1.7 \times 10^{-6}$; hexamethonium $4 \times 10^{-4}$. Hexamethonium was added in reverse order in cells 2,4 and 6.

* Mean difference not significant $(P>0.05)$.

Table 4 End-plate depolarization of curarized rat diaphragm by bath-applied acetylcholine in the absence and in the presence of hexamethonium

\section{Treatment}

Tubocurarine

Tubocurarine plus hexamethonium
No. of cells

13

13

Difference
Mean depolarization ( $m V$ )

$2.13( \pm 0.39)$

$1.92( \pm 0.23)$

$0.21 *$

Values given are means \pm s.e. mean.

Concentration (mol/l): acetylcholine, $4.0 \times 10^{-3}$; tubocurarine, $1.7 \times 10^{-6}$; hexamethonium, $4.0 \times 10^{-4}$.

" Not significant $(P>0.05)$. 


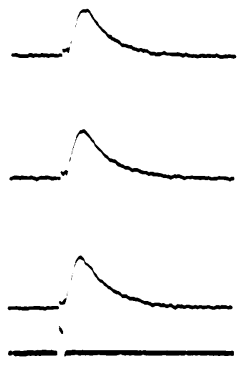

a
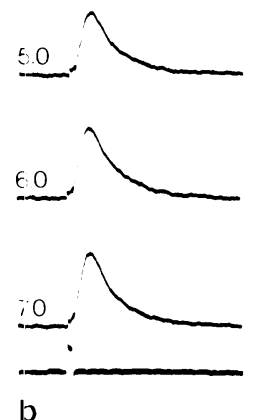
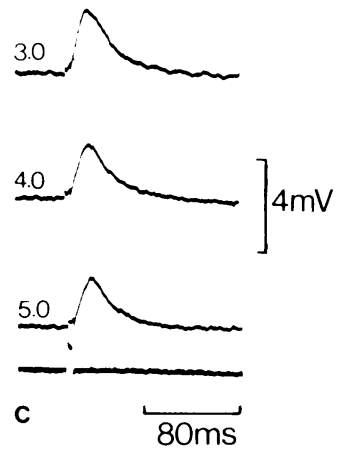

Figure 3 Effect in a curarized rat diaphragm preparation of hexamethonium $\left(4.0 \times 10^{-4} \mathrm{~mol} / \mathrm{l}\right)$ on the potential produced by iontophoretic application of acetylcholine. Numbers denote time in min after addition (between (a) and (b)) or withdrawal (between (b) and (c)) of hexamethonium. Tubocurarine: $1.7 \times 10^{-6} \mathrm{~mol} / \mathrm{litre}$.

a

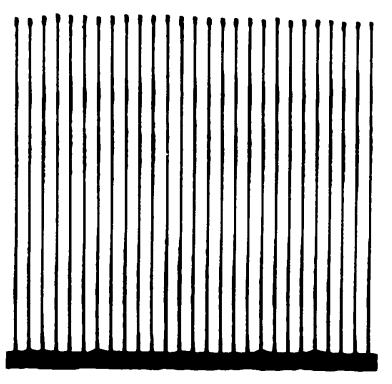

Tc

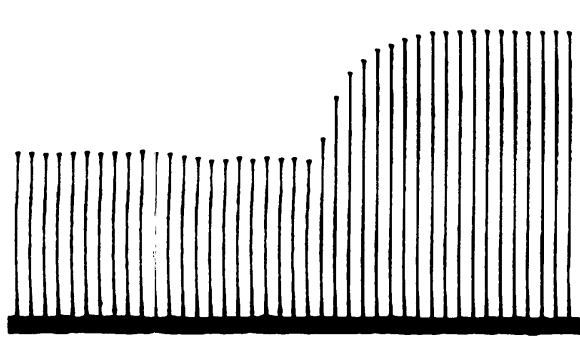

4

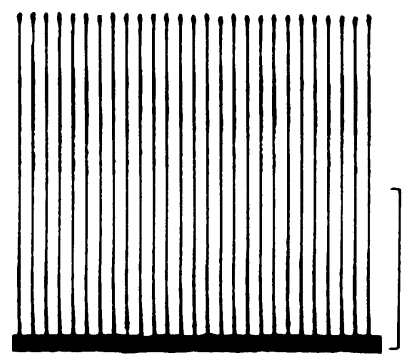

C6

b
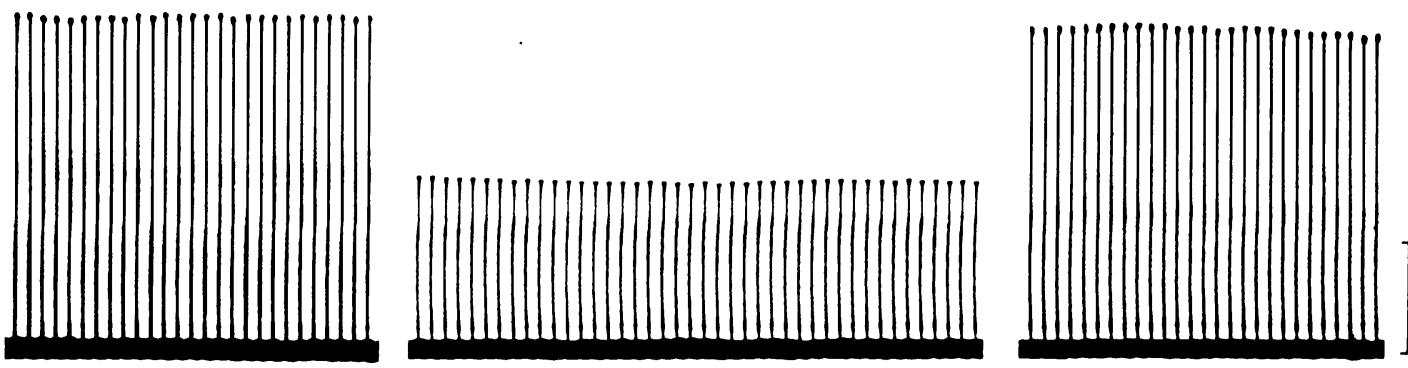

$5 \min$

TC

$\uparrow$

C6

Figure 4 The effect of hexamethonium (C6: $4.0 \times 10^{-4} \mathrm{~mol} / \mathrm{l}$ ) on twitch tension of an indirectly stimulated curarized rat diaphragm in the absence (a) and in the presence (b) of neostigmine $\left(3 \times 10^{-6} \mathrm{~mol} / \mathrm{litre}\right)$. At least $20 \mathrm{~min}$ was allowed for equilibration with tubocurarine. (Tc: approx. $1 \times 10^{-6} \mathrm{~mol} / / \mathrm{itre}$ ). Isometric recording, vertical calibration $0.1 \mathrm{~N}$. 
factors. We have considered three: temperature, ACh concentration, and the time course of events.

Temperature The anticurare effect of hexamethonium was observed in the rat diaphragm at temperatures ranging from $24^{\circ} \mathrm{C}$ to $37^{\circ} \mathrm{C}$, but could not be induced in the toad sartorius preparation by raising the temperature from $20^{\circ} \mathrm{C}$ to $37^{\circ} \mathrm{C}$.

Acetylcholine concentration Variation of stimulus frequency (from 0.06 to $2.0 \mathrm{~Hz}$ ) and of calcium levels (from 2 to $8 \times 10^{-3} \mathrm{~mol} / \mathrm{l}$ ) did not affect the anticurare action of hexamethonium in the rat diaphragm. We conclude that the effect is not critically dependent on the synaptic concentration of ACh during transmission.

Time course of events We attempted to modify the time course of synaptic events associated with a given degree of block in the rat diaphragm by simultaneously inhibiting acetylcholinesterase activity and adding tubocurarine to maintain the level of block. When this was done with neostigmine $\left(3 \times 10^{-6} \mathrm{~mol} / \mathrm{l}\right)$ the anticurare effect of hexamethonium was abolished (Figure 4b). Similarly, neostigmine abolished the effect in the guinea-pig and mouse preparations. Edrophonium $\left(5 \times 10^{-6} \mathrm{~mol} / \mathrm{l}\right)$, ecothiopate $\left(0.5 \times 10^{-6} \mathrm{~mol} / \mathrm{l}\right)$ and physostigmine $\left(5 \times 10^{-6} \mathrm{~mol} / \mathrm{l}\right)$ also abolished the effect in the rat diaphragm.

In addition, neostigmine $\left(3 \times 10^{-6} \mathrm{~mol} / \mathrm{l}\right)$ abolished the anti-curare effects of hexamethylene bisethyldimethylammonium, gallamine, and hyoscine butylbromide, and reduced that of azamethonium.

\section{Discussion}

It is evident from our results that the anti-curare effect of hexamethonium is but one example of a general phenomenon which is a consequence of the kinetics of the drug-receptor interaction. The phenomenon is confined to competitive antagonists and conforms qualitatively with the expectations of the hypothesis derived by Stephenson \& Ginsborg (1969) from the mass-law description of drug-receptor interaction. These authors have shown that a rapidly dissociating antagonist can reverse block by a slowly dissociating antagonist acting on the same receptors, provided exposure to the agonist is so brief that little dissociation of the slow antagonist occurs during its action: the slow antagonist thus completely excludes a fraction of receptors from occupation by the agonist. Equilibration with the rapidly dissociating antagonist reduces the fraction excluded and the agonist then competes with the fast antagonist for more receptors. Block is reversed.

In the terminology of Stephenson \& Ginsborg (1969) the conditions for reversal can be stated as follows. Let $y_{b}$ be the fraction of receptors occupied by the agonist $a$ in the presence of the slow antagonist $b$ alone, and let $y_{b c}$ be the fraction occupied by the agonist in the presence of both the slow antagonist $b$ and the fast antagonist $c$. Given that $b$ dissociates to a negligible extent during the application of the agonist $a$, but that $c$ dissociates sufficiently rapidly to equilibrate with the agonist, it can be shown that

$$
y_{b}=Y(1-Z)
$$

and

$$
y_{b c}=\frac{Y(1-X)(1-Z)}{(1-X Y)(1-X Z)}
$$

where $Y=$ fraction of receptors occupied by agonist acting alone

$X=$ fraction occupied by fast antagonist acting alone

$Z=$ fraction occupied by slow antagonist acting alone

The condition for reversal by $c$ of block by $b$ is therefore

$$
\frac{y_{b c}}{y_{b}}=\frac{1-X}{(1-X Y)(1-X Z)}>1
$$

a condition which we presume occurs in our experiments in the rat diaphragm. In the diaphragm, the transmitter, $\mathrm{ACh}$, acts rapidly and within a millisecond is removed by hydrolysis and diffusion (see Hubbard, 1973). It is thus likely, as Stephenson \& Ginsborg (1969) have observed, to fulfil the requirements of the agonist in the above scheme.

Tubocurarine almost certainly fulfils the requirements for the slow antagonist. It has been shown to be a competitive antagonist of $\mathrm{ACh}$ over a wide range of concentrations at the skeletal neuromuscular junction of the frog (Jenkinson, 1960 ) and of the guinea-pig lumbrical (Waud, Cheng \& Waud, 1973) and diaphragm muscles (Lu, 1970). Its affinity constant has not been measured in the rat diaphragm but is likely to be close to the value of $9 \times 10^{6} 1 / \mathrm{mol}$ measured in guinea-pig diaphragm and lumbrical muscles. Given this affinity constant and an upper limit of $2.5 \times 10^{9} 1$ $\mathrm{mol}^{-1} \mathrm{~s}^{-1}$ for the forward rate constant of the drug-receptor interaction (see Burgen, 1966), the half-time for dissociation of tubocurarine from the receptor must be at least 3 ms or greater.

Similar arguments can be applied to pancuronium, whose affinity constant is even larger than that of tubocurarine (Waud et al., 1973), and to alcuronium which is about as potent as tubo- 
curarine. Since the end-plate potential in the rat diaphragm has a time-to-peak usually less than $1 \mathrm{~ms}$, these three antagonists should dissociate only slightly, if at all, during transmission: their action should be effectively irreversible. There is indeed evidence that tubocurarine dissociates only slightly during neuromuscular transmission in the mammal (Paton \& Waud, 1967; Kruckenberg \& Bauer, 1971).

By contrast, the dissociation of hexamethonium from receptors could approach completion during transmission. Hexamethonium appears to act as a competitive antagonist of $\mathrm{ACh}$ with an affinity constant of about $2.5 \times 10^{4} \mathrm{l} / \mathrm{mol}$ (Ariëns, van Rossum \& Simonis, 1956). Its corresponding half-dissociation time could be about one hundredth that of tubocurarine, that is $10 \mu \mathrm{s}$ or greater. A large fraction of hexamethonium-receptor complexes may therefore dissociate during brief application of the transmitter, and hexamethonium may thus fulfil the requirements for the fast antagonist $c$. Similar arguments apply to the other low-potency competitive antagonists tested.

Antagonists which dissociate less rapidly than hexamethonium should have less anti-curare effect. Thus the anti-curare effect of gallamine was weaker than that of hexamethonium. It must be supposed that the dissociation rate of gallamine is not slow enough to allow hexamethonium to antagonize its blocking action (Ferry \& Marshall, 1971), although the theory does not exclude the possibility of a compound acting as both a fast and slow antagonist.

Our argument, so far, supports the view that the Stephenson-Ginsborg hypothesis explains the anti-curare effect of hexamethonium and related observations. We believe, however, that the theory in its given form provides no more than a general description of events, for certain assumptions implicit in the hypothesis may not be fulfilled at the neuromuscular junction.

The mathematical formulation assumes that the agonist is applied uniformly to the receptor population and that it equilibrates with the receptors. However, at the skeletal neuromuscular junction, application of $\mathrm{ACh}$ is unlikely to be uniform, for it is released asynchronously and from a number of discrete sites (Dreyer, Peper, Akert, Sandri \& Moor, 1973; Hubbard, 1973). Equilibration may not occur either for if, as has been argued, ACh has an affinity constant for the receptors of $10^{6} 1 / \mathrm{mol}$ or greater (Eldefrawi, 1974), it can be expected to dissociate with a half-time of at least 0.3 millisecond. This is a substantial fraction of its lifetime in the cleft and must preclude it from coming to equilibrium. As it happens, this is of no consequence to our explanation, which requires only that dissociation of hexamethonium from receptors should take place rapidly enough to allow acetylcholine to achieve high occupancy before tubocurarine begins to dissociate.

It follows that the anti-curare effect should be critically dependent on the rate of occupation of receptors by the agonist. The rate of occupation of receptors by $\mathrm{ACh}$ released from the nerve terminal is unfortunately not easily controlled experimentally, for release is in quanta from discrete sites within the cleft. Some control can be achieved, however, by applying $\mathrm{ACh}$ by diffusion from outside the cleft. Thus we have observed that the effect does not occur in the rat diaphragm when $\mathrm{ACh}$ is applied from the bath, but does occur when ACh is applied by iontophoresis. We assume in the latter case that the concentration gradient is steep enough to achieve high occupancy of successive populations of receptors before tubocurarine dissociates appreciably. By contrast, the rate of application of $\mathrm{ACh}$ from the bath is limited by the time for mixing and must be very much slower.

We have also taken as evidence of the dependence of the effect on rate of occupation of receptors our finding that anticholinesterase agents abolish the anti-curare effect of hexamethonium. Our argument runs as follows. When the esterase is inhibited, more tubocurarine must be present to maintain the same degree of block. Under these circumstances, although the amplitude of the response is the same as that before the cholinesterase was inhibited, the time course of the response to $\mathrm{ACh}$ is prolonged. In particular, the time-to-peak of the response is longer, which implies that the rate of occupation of receptors is slower. There is evidence also that when cholinesterase is inhibited, ACh diffuses laterally from its presynaptic release sites to more distant receptors (Negrete, del Castillo \& Escobar, 1972) and activates receptors in succession before being removed by diffusion from the synaptic cleft (Katz \& Miledi, 1973a). Tubocurarine should, therefore, dissociate to an appreciable extent before ACh achieves adequate occupancy of receptors. In consequence, hexamethonium will have no anti-curare effect. It may be noted in passing that the anti-curare effects of the other weak antagonists tested in our experiments were also abolished by neostigmine. This is consistent with our belief that they share with hexamethonium the same mechanism of anti-curare action.

Two factors may conspire to ensure that hexamethonium should have no anti-curare effect in the toad sartorius preparation: the rate of occupation of receptors by the transmitter may be 
slower in the amphibian than in the mammal, and tubocurarine may dissociate more rapidly from receptors in the amphibian than in the mammal. One measure of the rate of occupation of receptors is the rise time of the end-plate current. As it happens, there appears to be little difference 'at the end-plates of frog and rat in the time-to-peak of the synaptic current due to a single quantum of ACh (150-300 $\mu \mathrm{s}$ : Gage \& Armstrong, 1968). However, the time-to-peak of the end-plate current will depend also on the degree of asynchrony in release of quanta of transmitter: it would be interesting to compare the rise time of the end-plate current in the rat diaphragm with that in the toad sartorius muscle.

In addition, tubocurarine appears to dissociate more rapidly from amphibian than from mammalian muscle receptors. Thus as an antagonist of iontophoretically applied $\mathrm{ACh}$ at the motor end-plate, tubocurarine is 20 times less effective in the frog than in the rat (Beránek \& Vyskocill, $1967,1968)$. Also, the affinity constant in the frog is three times lower than in the guinea-pig (Jenkinson, 1960; Lu, 1970; Bowen, 1972; Waud et al., 1973) and in the toad rectus abdominis muscle is lower by a factor of 15 or more (Blackman \& Milne, unpublished results). We conclude, therefore, that anomalous interaction of hexamethonium and tubocurarine does not occur in the amphibian because, for one or both of the reasons discussed above, tubocurarine is able to dissociate significantly from receptors during application of the transmitter.

\section{References}

ARIËNS, E.J., VAN ROSSUM, J.M. \& SIMONIS, A.M. (1956). A theoretical basis of molecular pharmacology. Arzneimittel-Forsch., 6, 282-293.

BERÁNEK, R. \& VYSKOCĺL, F. (1967). The action of tubocurarine and atropine on the normal and denervated rat diaphragm. J. Physiol., Lond., 188, 53-66.

BERANEK, R. \& VYSKOCǏL, F. (1968). The effect of atropine on the neuromuscular junction of the frog. $J$. Physiol., Lond., 195, 493-503.

BOWEN, J.M. (1972). Estimation of the dissociation constant of d-tubocurarine and the receptor for endogenous acetylcholine. J. Pharmac. exp. Ther., 183, 333-340.

BURGEN, A.S.V. (1966). The drug-receptor complex. $J$. Pharm. Pharmac., 18, 137-149.

DREYER, F., PEPER, K., AKERT, K., SANDRI, C. \& MOOR, H. (1973). Ultrastructure of the 'active zone' in the frog neuromuscular junction. Brain Res., 62, 373-380.

ELDEFRAWI, M.E. (1974). Neuromuscular transmission-the transmitter-receptor combination. In The
Finally, our results allow calculation of the half-time for dissociation of tubocurarine from receptors in the rat diaphragm. If tubocurarine remains bound to receptors during the rise-time of the end-plate potential (about $0.7 \mathrm{~ms}$ ) but dissociates significantly when the rise-time is prolonged by inhibition of cholinesterase, we can conclude that the half-dissociation time for tubocurarine is not less than $0.7 \mathrm{~ms}$ and is not greater than the time-to-peak of the prolonged end-plate potential. It is therefore likely to be about 1 millisecond. Assuming this value of half-time for dissociation and an affinity constant of $9 \times 10^{6} 1 / \mathrm{mol}$, it follows that the forward rate constant for binding to receptors is about $6 \times 10^{9} 1 \mathrm{~mol}^{-1} \mathrm{~s}^{-1}$. This compares with the theoretical maximum rate constant for diffusionlimited binding $\left(2.5 \times 10^{9} \mathrm{l} \mathrm{mol}^{-1} \mathrm{~s}^{-1}\right.$ : Burgen, 1966). This is a satisfactory consequence of our explanation of the anti-curare effect of hexamethonium. It incidentally implies that binding of tubocurarine to the ACh receptors of mammalian diaphragm muscle is diffusion limited.

Note added in proof The reader is referred to a full account of the Stephenson-Ginsborg hypothesis which has appeared since our paper was written (GINSBORG, B.L. \& STEPHENSON, R.P. (1974). On the simultaneous action of two competitive antagonists. Br. J. Pharmac., 51, 287-300).

This work was supported by a grant from the Medical Research Council of New Zealand.
Peripheral Nervous System, ed. Hubbard, J.I. pp. 181-200. New York: Plenum Press.

FERRY, C.B. \& MARSHALL, A.R. (1971). An anti-curare effect of hexamethonium at the mammalian neuromuscular junction. Br. J. Pharmac., 41, 380-381P.

FERRY, C.B. \& MARSHALL, A.R. (1973). An anti-curare effect of hexamethonium at the mammalian neuromuscular junction. Br. J. Pharmac., 47, 353-362.

GAGE, P.W. \& ARMSTRONG, C.M. (1968). Miniature end-plate currents in voltage-clamped muscle fibres. Nature, Lond., 218, 363-365.

HUBBARD, J.I. (1973). Microphysiology of vertebrate neuromuscular transmission. Physiol. Rev., 53, 674-723.

HUBBARD, J.I., LliNÁS, R. \& QUASTEL, D.M.J. (1969). Electrophysiological Analysis of Synaptic Transmission, p. 133. London: Edward Arnold Ltd.

JENKINSON, D.H. (1960). The antagonism between tubocurarine and substances which depolarize the motor end-plate. J. Physiol., Lond., 152, 309-324. 
KATZ, B. \& MILEDI, R. (1973a). The binding of acetylcholine to receptors and its removal from the sy naptic cleft. J. Physiol., Lond., 231, 549-574.

KATZ, B. \& MILEDI, R. (1973b). The effect of atropine on acetylcholine action at the neuromuscular junction. Proc. R. Soc. B, 184, 221-226.

KRUCKENBERG, P. \& BAUER, H. (1971). Die Dissoziationskonstante zwischen Curare und dem Acetylcholin-Receptor. Pflügers Arch., 326, 184-192.

LU, T. (1970). Affinity of curare-like compounds and their potency in blocking neuromuscular transmission. J. Pharmac. exp. Ther., 174, 560-566.

NEGRETE, J., DEL CASTILLO, J. \& ESCOBAR, I. (1972). Spreading activation of end-plate receptors by single transmitter quanta. Nature, New Biol., 235, 158-159.

PATON, W.D.M. \& WAUD, D.R. (1967). The margin of safety of neuromuscular transmission. J. Physiol., Lond., 191, 59-90.

STEPHENSON, R.P. \& GINSBORG, B.L. (1969).
Potentiation by an antagonist. Nature, Lond., 222, 790-791.

TRENDELENBURG, U. (1961). Observations on the mode of action of some non-depolarizing ganglionblocking substances. Naunyn-Schmiedebergs Arch. exp. Path. Pharmak., 241,452-466.

VAN ROSSUM, J.M. \& ARIËNS, E.J. (1959). Pharmacody namics of drugs affecting blood pressure. Structureaction relationships of quaternary ganglionic and parasympathetic drugs. Arch. int. Pharmacodyn. Thér., 118, 447-466.

WAUD, B.E., CHENG, M.C. \& WAUD, D.R. (1973). Comparison of drug-receptor dissociation constants at the mammalian neuromuscular junction in the presence and absence of halothane. J. Pharmac. exp. Ther., 187, 40-46.
(Received August 5, 1974. Revised November 29, 1974) 